\title{
FGF6 Gene
}

National Cancer Institute

\section{Source}

National Cancer Institute. FGF6 Gene. NCI Thesaurus. Code C18412.

This gene is involved in angiogenesis and cell proliferation. 